PhDr. Andrej Nikulin, PhD.

Prešovská univerzita $\vee$ Prešove,

Pravoslávna

bohoslovecká fakulta
Eliminacja wykluczenia społecznego, red. M. Duda, K. Kutek-Sładek, Kraków 2017, s. 27-35 (Praca Socjalna w Teorii i Działaniv, 3).

DOI: http://dx.doi.org/10.15633/9788374385824.03

\title{
Aplikácia moderných psychoterapeutických prístupov pri práci s dysfunkčnou rodinou
}

\author{
The application of modern psychotherapeutic \\ approaches when working with dysfunctional families
}

\begin{abstract}
The paper aims to draw attention to the importance of family and the need for effective prevention and therapy as the means for solving marital crises and conflicts. As a tool of effective therapy, the therapist can use modern approaches in contemporary individual and couple therapy which are based on the principles of solution-oriented therapy and which also serve the widening of perspectives of the relationship, the interactions within the couple, and which also increase the competencies of clients for solving similar situations in the future. The solution-oriented therapy approach philosophy contains the assumption that any assistance provided to an individual is always better if it strengthens their family as a whole. In this approach, the assistance being
\end{abstract}

provided originates from cooperation with the family and draws on its internal resources. One of the strengths of this approach is understanding the family as an advisory and therapeutic partner, who participates in the setting of therapy objectives. This cooperation takes advantage of the strengths and resources of the family, enabling them to see their competencies and options for driving their lives. This results in a strengthened family, which is able to build favorable emotional background for its members, with extra emphasis on children. With this kind of assistance, families are then able to function independently and with minimum of external interventions.

Keywords: family, therapy, spirituality, support, client 
Úloha a miesto rodiny $\mathrm{v}$ spoločenskom kontexte a rozvoji jednotlivca je zdôrazňovaná na úrovni všetkých spoločenskovedných disciplín. Pre sociológiu je rodina pôvodnou a najdôležitejšou spoločenskou skupinou a inštitúciou. Psychológia chápe rodinu ako primárnu skupinu, ktorá sa vyznačuje intimitou, vysokou súdržnostou, emocionalitou a autentickostou na základe silných citových väzieb v jej vnútri. Svoje nezastupitel'né miesto má rodina vo všetkých významných náboženstvách. $\mathrm{V}$ krestanskej tradícii je rodina vnímaná ako dôležitý duchovný systém. Apoštol Pavol zdôrazňuje duchovnú stránku rodiny, používa výraz „malá" alebo „domáca Cirkev“. Tak ako v Cirkvi, podla apoštola Pavla, aj v rodine sa jednotliví členovia majú spájat vzájomnou láskou, úctou a vierou v Boha. Na druhej strane je Cirkev sama v niektorých veciach inšpirovaná životom človeka v rodine a vytvára rodinnú atmosféru, ked' kňaza nazýva „otcom duchovným“ a veriacich „duchovnými detmi“.

Rodina $\mathrm{v}$ živote jedinca má dôležité miesto a pre jeho formovanie zohráva rozhodujúcu a nezastupitelnú úlohu ${ }^{1}$. Jej vplyv je dôležitýa cítitelný najmä u detí $\mathrm{v}$ útlom veku a v období dospievania. Pre deti sa rodina stáva primárnym zdrojom zabezpečenia potrieb, počnúc biologickými končiac duchovnými, rodina stimuluje a usmerňuje vývin diełata do zrelej integrovanej osobnosti, je zdrojom skúseností a vzorom správania, ktoré získava dieta. Každá rodina je nositelom špecifických hodnôt, ktoré ovplyvňujú jej dynamiku a interakciu s vonkajším prostredím. Rodina je zároveň otvoreným systémom, ktorý funguje vo vztahu k širšiemu sociokultúrnemu kontextu, a ktorý sa vyvíja počas životných cyklov. Fisher hodnotí rodinu ako najdôležitejšiu sociálnu skupinu, v ktorej človek žije 2 . Rodina zohráva velkú úlohu vo výchove zrelého jedinca, a preto je mnohými vnímaná ako základná spoločenská bunka.

Napriek tomu, že existuje množstvo definícií, ktoré sa snažia rodinu nejako vystihnút a kategorizovat’ $\mathrm{v}$ praxi sa stretávame $s$ tým, že každá rodina je jedinečná a neopakovatel'ná. Rodina, tak ako jedinec, nikdy nie jej statickou, je vždy dynamická, v rôznych svojich štádiách a obdobiach prechádza mnohými zmenami. Zmeny sa týkajú rolí, ktoré so založením rodiny pribúdajú a funkcií, ktoré súvisia s plnením týchto rolí. Velmi často zmeny spôsobujú takzvané krízy rodiny, ktoré odborníci vnímajú nielen ako rizikový faktor, ale aj istú príležitost' ku zmene. Kríza je niečo, čo by sa malo diat a z akého si dôvodu sa to nedeje, môže znamenat zhoršenie situácie alebo jej úplnú zmenu k lepšiemus3. Pri pomáhaní rodine v stave krízy je potrebne pamätat, že cielom pomoci nemusí byt

\footnotetext{
Pozri R. Koteková a kol., Psychológia rodiny, Košice 1998, s. 8.

Pozri S. Fischer, Sociální patologie. Analýza př́čin a možnosti ovlivňování závažných sociálně patologických jevư, Praha 2009.

3 Pozri i. k. Berg, Posílnení rodiny, Praha 2013, s. 145.
} 
návrat k pôvodnému stavu ale rozvíjanie a posilnenie zmien, ktoré sa v rodine odohrávajú.

Podla toho ako rodina zvláda svoju funkciu a ako vie riešit problémy alebo krízy, sa rozlišujú rodiny: funkčné, problémové, dysfunkčné a afunkčné. Definovat' funkčnú alebo normálnu rodinu môže byt’ obtiažné vzhl'adom na množstvo kritérií a pohladov. Všeobecne sa za funkčnú rodinu považuje taká rodina, v ktorej sú uspokojené potreby všetkých jej členov, integrovaná v širšom sociálnom prostredí a vychováva sociálne orientovaných potomkov ${ }^{4}$. Pod pojmom afunkčná sa chápe rodina, ktorá neplní základné funkcie a ohrozuje existenciu jednotlivých členov, najmä detí. Taká rodina funguje asociálne, presne povedané nefunguje vôbec. Poruchy tejto rodiny sú tak závažné a motivácia ku zmene je tak nízka, že je vel’mi tažko s takou rodinou pracovat'. Väčšinou sa jedná o rodiny s problémom alkoholizmu, týraním a zneužívaním detí atd'. Medzi týmito protipólmi sa nachádzajú d’alšie dve skupiny rodín problémové a dysfunkčné. Rozdiel medzi týmito typmi spočíva v tom, že problémová rodina síce potrebuje dohlad a podporu zo strany odborníkov, ale dokáže sama vyriešit svoj problém. Dysfunkčná rodina je tá, ktorá vyžaduje sústavnú pomoc a sanáciu zo strany odborníkov ${ }^{5}$.

Velkým problémom dysfunkčných rodín sú deti, ktoré sa stávajú rukojemníkmi a obetami problémov v rodine. Pri riešení rodinných problémov je dôležité, aby mal sociálny pracovník vždy na vedomí to, že týrané deti alebo deti z dysfunkčných rodín, okrem pocitov nenávisti a hnevu prechováva ku rodičom aj pocit lásky, túžia po rodičoch a potrebujú mat̉ nádej, veria, že rodič sa raz zmení a všetko bude fungovat' normálne ${ }^{6}$. Rodina, aj ked’ je dysfunkčná, má pre dieta vel'ký význam a hodnotu. Dieta potrebuje vyrastat v rodine, ale zároveň potrebuje, aby rodina fungovala. Pre odborníka, ktorý takej rodine pomáha, predtým ako „vynesie verdikt“, sa treba uistit, či všetko spravil a využil pre to, aby rodine pomohol vyriešit problém alebo prekonat krízu. To všetko vyžaduje od pracovníka nielen znalost’ sociálnej problematiky a právnych noriem, ale aj základy komunikačných zručností, ktoré sú spracované v moderných psychoterapeutických prístupoch.

Moderné psychoterapeutické prístupy sú výsledkom zmien, ktorými prešla terapia jednotlivca a rodiny od 50. rokov minulého storočia. V rodinnej terapii správanie jednotlivca je odvodzované od kontextu jeho prostredia (rodiny), ktoré jeho správanie ovplyvňuje. Rodinná terapia definuje problém ako interakciu

4 Pozri J. Prevendárová, Rodinná terapia a poradenstvo, Bratislava 2011, http://www.terapeutickecentrum.com/wp-content/uploads/2010/06/kniha.pdf (cit. 10.5.2015).

5 Pozri S. Fischer, Sociální patologie. Analýza př́ćin..., op. cit., s. 143.

6 Pozri i. k. Berg, Posílnení rodiny, Praha 2013, s. 16. 
medzi jednotlivými členmi rodiny. Pokial’ nastane zmena v interakcii medzi nimi potom môžu nastat' aj zmeny v správaní u jednotlivca a ked’ sa zmení on, to spätne ovplyvní celú rodinu. Rodinná terapia ukázala, že riešenie v rámci interakčného kontextu sa rozvíja $\mathrm{v}$ závislosti od toho, že aspoň jeden $\mathrm{z}$ členov urobí niečo iné, než sa od neho očakáva7. Rodinná terapia chápe rodinu ako systém, ktorý má zachovávat' homeostázu a zachovat svoje hranice. Na rozdiel od takého prístupu moderná terapia zdôrazňuje nevyhnutnost’ zmeny, ktorá je a deje sa neustále. Na základe toho pozornost’ sa sústred’uje na výnimky z problémového systému a rozvíja ich.

Filozofia moderných prístupov sa dá chápat ako činnost' zameraná na podporu a posilnenie rodiny ${ }^{8}$. Jednou $\mathrm{z}$ foriem modernej terapie je terapia zameraná na riešenie, ktorá sa líši od klasických terapeutických postupov aj od rodinnej terapie tým, že má úplne iný pohlad na problém a jeho riešenie v kontexte rodiny. Klasický terapeutický prístup tzv. objektivistický, vníma problém ako objektívnu danost', akúsi pravdu o klientovi, ktorú potrebujeme odhalit', a zvládnut odbornými terapeutickými postupmi. Riešit problém znamená odstránit príčiny, dostat sa k jadru, ktoré je ukryté pod povrchom bez ohladu na to, ako klient vníma problém. Taký pohlad na problém sa spája s direktívnym prístupom k jeho riešeniu. Odborník vystupuje ako kompetentný, jednosmerne kontroluje vztah s klientom, ponúka klientom „hotové“, „správne“ riešenie. Ako prirodzená reakcia na kontrolu a ovládanie vzniká u klienta pocit ohrozenia a pokus o zmenu moci ${ }^{9}$. Na druhej strane analýza a skúmanie problému nie je cestou k jeho riešeniu. Cesta vzniku problému, tak ako aj jazyk problému, sa líši od cesty a jazyka riešenia. Podl’a Shazera cesta riešenia je iná ako cesta vzniku problému ${ }^{10}$.

Neriešit’ problém neznamená vyhýbat sa mu alebo sa tvárit, že neexistuje. Z praktickej skúsenosti je jednoduchšie a účinnejšie konštruovat’ riešenie ako analyzovat' a odstraňovat' problém. Dokonca prax ukazuje, že správanie človeka, jeho reč, je odlišná, ked’ sa zameriame na riešenie, od toho, ako ked'sa zameriavame na problém. Problém, s ktorým klient prichádza sa chápe ako jeden $\mathrm{z}$ mnohých pokusov o riešenie, ako pokus zd’aleka nie jediný a zd’aleka nie najhoršíi ${ }^{11}$.

V̌̌eobecne nájst' „objektívnu“ odpoved’ na otázku, čo je problém, je vel'mi obtiažné. Pravdepodobne odpovedí bude tolko, kol'ko ludí je do problému zapojených. Pričom sa pohlady môžu rôznit. Bergová odporúča priblížit sa čo najviac

\footnotetext{
Pozri i. k. Berg, Posílnení rodiny, op. cit., s. 23.

Pozri i. k. Berg, Posílnení rodiny, op. cit., s. 23.

9 Pozri S. Pecháčková, O systemické terapii, Praha 1992, s. 47.

10 Pozri S. Shazer, Zázračná otázka, Praha 2011.

11 Pozri i. k. Berg, Posílnení rodiny, op. cit.
} 
klientovej definícii, nakol'ko on bude ten, kto potrebuje uskutočnit' nevyhnutné zmeny. Zároveň je dôležité aby problém, na ktorom sa zhodneme, bol riešitelný klientovými zdrojmi. Pokial' sa jedná o spoluprácu s rodinou, je dôležité zistit', kto je problémom najviac znepokojený a rozrušený a mohol by pre vyriešenie situácie urobit najviac. Takého človeka v rodine prezrádzajú silné emócie, ktoré sa prejavujú v rozhovore o probléme, rozrušenie a znepokojenie, záujem o zmenu, hladanie riešenia a snaha s tým niečo urobit’. Velmi dôležitým znakom pre začiatok spolupráce je nádej a viera v to, že sa situácia môže zlepšit’. Je omnoho lahšie a efektívnejšie pracovat tam, kde existuje snaha a vôla hladat' riešenie problému. Preto cielom práce s klientom nie je rozoberat’ a opravovat', čo nefunguje, ale posilňovat' a rozvíjat čo funguje. Za týmto účelom je dôležité poznat' silné stránky rodiny. Pričom sa vychádza z predpokladu, že každá, aj tá najproblémovejšia rodina sa $\mathrm{v}$ minulosti stretla $s$ úspešným zvládaním nejakej preň kritickej situácie a existovalo niečo, čo rodinu držalo pokope. To hovorí o tom, že v dispozíciách rodiny sú zdroje a sily pre zvládanie mnohých tažkých situácií. Niekedy sa spôsob, ako situácie boli zvládané líši od bežných zaužívaných v danej kultúre, ale dôležitým podla Bergovej je, že to fungovalo a pomohlo rodine problém vyriešit'. Ako nástroj pre vytvorenie kontextu spolupráce sa používajú otázky, ktorými sa hladajú výnimky v skúsenostiach klienta, hladá sa kedy, a za akých okolností silné stránky fungovali. Velký dôraz sa kladie na úvodný rozhovor s klientom, pripadne rodinou.

Prístup zameraný na riešenie kladie vel'ký nárok na jednanie pracovníka. V prvom rade sa mení kontext vztahu medzi klientom (rodinou) a pracovníkom (sociálnym pracovníkom, terapeutom, poradcom). Namiesto direktívneho („odborného") prístupu, v ktorom nositelom správneho riešenia je pracovník, vzniká kontext interakcie medzi klientom a pracovníkom, nový sociálny systém, ktorý je zameraný na hladanie riešenia problému klienta (rodiny). Úloha pracovníka v tomto vztahu je dôležitá, ale nie rozhodujúca. Významné miesto sa dáva klientovi ako spoluautorovi riešenia svojho problému. Pracovník klientovi aktívne pomáha hladat zmeny, ktoré nastali pred prvým stretnutím, premýšla o výnimkách z problému, pomáha konštruovat riešenie, kladie klientovi otázky štýlom, ktorý pomôže klientovi samostatne objavovat vlastné riešenia ${ }^{12}$. Preto od pracovníka sa očakáva, že bude bezprostredne odpovedat' na potreby rodiny, postupovat’ pružne. Taký štýl práce vyžaduje tvorivý prístup a množstvo konštruktívnych nápadov. Riešenie, ktoré vzniká zo systému spolupráce medzi klientom a terapeutom, a na vzniku ktorého má klient výrazný podiel, je lepšie prijatel'né, dlhodobo udržatel'né a má celkovo pozitívnu dynamiku. Pri hladaní riešenia pracovník nesmie zabúdat na základné jednoduché princípy, ktorých sa drží

12 Pozri i. k. Berg, Posílnení rodiny, op. cit., s. 28. 
krátkodobá, na riešenie zameraná terapia: neopravovat to, čo nie je pokazené, viac robit' to, čo funguje a ked' niečo nefunguje, nerobit' to ${ }^{13}$.

Pri akejkolvek práci s klientom je dôležitý vzt’ah medzi klientom a pracovníkom. Pokial' tento vztah je kladný, zvyšuje sa aj šanca na dosiahnutie dobrých výsledkov terapie. Samozrejme vztah v terapii nie je cielom, ale prostriedkom ku dosiahnutiu jej úspešnosti a sám od seba nestačí na zmeny v správaní klienta. K skutočným zmenám dôjde vtedy, ked’ klient zmení vnímanie a myslenie a začne robit niečo iné ako doposial'.

Výhodou krátkodobej terapie je intenzita jej práce od prvého stretnutia. Naštartovanie úspešnej intervencie a cenné informácie pre terapiu môže pracovník získat zo zmien, ktoré sa odohrávali pred prvým stretnutím. Rovnako dôležité je zistit, čo všetko v minulosti klient robil s týmto problémom, s akým typom pomoci sa stretol, a čo presne mu pomohlo. V množstve informácii o rodine, s ktorými sa pracovník stretne, je dôležité zistit, ktorá téma je pre klienta alebo rodinu najdôležitejšia, kto v rodine môže byt' najvplyvnejšou osobou, a čo by sa rozhodne nemalo robit’ s touto rodinou. Vytvorit predstavu o rodine pomôže osobná návšteva, ktorú sociálny pracovník môže uskutočnit'.

Pri nej sa odporúča okrem všeobecných postupov ako priniest dobrú a pozitívnu atmosféru byt' neformálnym a uvolneným, snažit sa používat bežný hovorový jazyk, mat priatel'ský tón, správat’ sa ako pri šálke kávy, ale pamätat', že ste v práci a konverzácia s klientom je nástrojom zmeny. Velmi dôležité pri práci s klientom je verit’ mu a verit’ v zmenu, ktorú očakávame, udržiavat' pozitívny postoj voči nemu, oceňovat’ snahu a zmeny, ktoré klient alebo rodina vykonala.

Rodinná terapia zaviedla pojem pripojenie, ktorý sa rovnako používa v terapii zameranej na riešenie. Je to popis toho, čo potrebujeme urobit v počiatočnej fáze našej práce, aby bol dosiahnutý pozitívny pracovný vztah. Podla Bergovej sú to tieto kroky:

- Pred prvým stretnutím si skúste predstavit čo, by ste ako klient chceli, aby pracovník pre vás mohol urobit'.

- Opustite profesionálny žargón a začnite používat jednoduchý slovník. Vyhýbajte sa odborným výrazom napr. „úroveň vzdelania“, „evidencia“, „abúzus“, „status“ atd”.

- Využit prvé stretnutie pre vytvorenie pozitívnej nálady, používat priatel'ské a povzbudivé slova. Brat' ohlad na to, čo má klient sklon bránit', a byt' $\mathrm{v}$ tom velmi opatrným. Zdôrazňovat to, že našou úlohou je bránit’ rodinu a snažit sa udržat v nej pohodu.

- Všímat si klúčové slová klienta, a to ako ich používa a snažit sa zakomponovat ich do svojej reči, príp. otázok.

13 Pozri i. k. Berg, Posílnení rodiny, op. cit., s. 29. 
- Dávat najavo, že prijímame správanie klienta, jeho videnie a vysvetlovanie veci. Pokial pre nás to, čo hovorí klient, nemusí dávat logiku, pre neho to môže byt' opak. Tieto nedorozumenia sú vel'mi dobrým podkladom pre vyjasňovanie vecí. Velmi vhodná je na to dekonštrukcia.

- Vyhýbat sa priamej konfrontácii s klientom, ktorá by ho nútila bránit sa, vyhýbat sa hádkam s klientom. Všetko sa dá vysvetlit pokial" zaujmeme pozíciu „hlúpeho“ a poprosíme veci vysvetlit. Vä̌šina z nás, nevynímajúc klientov, chce pomáhat druhým a ukázat ako vela toho vie.

- Dopriat' klientom pocit, že je „expertom“ na vlastný problém. Vyhýbat” sa tomu, že budeme sami poukazovat a pomenovávat problém, aký klient má. Pracovník by sa nemal dostat do pozície, kedy klient nebude súhlasit $\mathrm{s}$ jeho predpokladom, lebo potom sa sám stáva tým, kto má problém a potrebuje ho vyriešit.

- Namiesto očakávania, že klient príjme náš spôsob uvažovania, snažme sa pristúpit na jeho spôsob myslenia a správania. Ušetríme si tak čas, prácu a úsilie.

- Pri práci s rodinou zachovat' nestrannost' a neutralitu, ale podporovat všetky zmeny a prácu, ktorá vedie ku zlepšeniu situácie.

- Svoj jazyk prispôsobit chápaniu klienta, reflektovat jeho úroveň. Rozprávat's klientom o tom, čo je pre neho dôležité jemu zrozumitelným spôsobom a rečou. Reflektovat klienta ${ }^{14}$.

Pre efektivitu práce je dôležité pracovat na cieloch, ktoré by mali splñat nasledujúce kritériá. Mal by to byt $v$ prvom rade ciel:

- významný a dôležitý pre klienta

- začiatok nejakej činnosti, nie koniec (napr. namiesto prestane kričat', začnú sa viac spolu rozprávat')

- mat sociálny a interakčný kontext. Čo by sa malo zmenit na druhom, čo chce druhý, aby sa zmenilo na mne, čo chcem zmenit na sebe

- malý, jednoduchý a dosiahnutel’ný

- o ktorom si klient predstavuje, že ho dosiahnutie bude stát velké úsilie

- ktorý rešpektuje klientove možnosti nie ambície terapeuta

- formulovaný v behaviorálnych termínoch ${ }^{15}$.

- Dobre sformulovaný ciel výrazne ulahčí a zefektívni spoluprácu s klientom, a je polovicou, ked' nie celým úspechom spolupráce.

Dôležitým nástrojom spolupráce zostávajú otázky, ktoré kladie pracovník počas rozhovoru, a ktoré smerujú ku vytváraniu klientom bezproblémového riešenia jeho životnej situácie. Podla typu otázok sú otázky zistovacie

\footnotetext{
14 Pozri i. k. Berg, Posílnení rodiny, op. cit., s. 54.

15 Pozri S. Pecháčková, O systemické terapii, op. cit., s. 68.
} 
(anamnestické), inštruktívne (ponúkajú pohlad od poradcu), reflexívne (otázky na vlastné prežívanie) a cirkulárne, velmi dôležitá skupina otázok zameraných na ciele spolupráce, zdroje zvládania tažkých situácií, na riešenie -otázky týkajúce sa samotnej zmeny.

Pri práci s párom alebo rodinou môžu byt použité nasledujúce metódy:

Oceňovanie - používa sa často ako prvá technika a môže byt účinnou na začiatku intervencie. Oceňovanie nemusí byt nutne spojené s problémom a jeho zvládaním, ale môže sa týkat čohokolvek, upravenosti klienta, jednania s deṫmi, poriadku v byte, udržiavania dobrých vztahov s okolím, čokolvek čo klienta dokáže posilnit, jeho sebaúctu a pocit kompetentnosti. Táto technika má vyvolat u klienta pozitívny pohlad na seba, ktorý ho bude motivovat robit dalšie pozitívne veci pre seba a rodinu. Klient nepremýšla obvykle o bežných veciach, ktoré robí. Potrebuje preto spätnú väzbu o tom, že to robí dobre. Vel'kú úlohu pri tom zohráva, že to počuje od odborníka.

Normalizácia - ide o techniku uistujúcu klienta, že to, čo robí, nevybočuje za daných náročných okolností z bežného normálneho ludského správania. Toto má klienta ukludnit', že ich správanie, myslenie a cítenie nie je bláznivé, mimo normu, ale spadá do oblasti normálnych ludských reakcií.

Preznačkovanie - táto technika sa velmi často používa v rodinnej terapii. Predstavuje jemný, ale účinný spôsob ako pomôct̉ klientom vidiet’ obtiažnu situáciu $\mathrm{v}$ inom svetle. Je to akýsi pozitívny výklad problémových interakcií klienta s prostredím, prostredníctvom ktorého sa otvára nový odlišný spôsob správania. Napr. hádanie sa, môže byt známkou nezávislosti alebo hlbokej starostlivosti. Je jasné, že človek označený depresívnostou bude jednat inak, ako keby bol označený ako tichý, obrátený do seba. Preznačkovaním vlastného správania mu pomôžeme mysliet', cítit a jednat inak.

Externalizácia - velmi známa technika, ktorá sa používa aj v naratívnej praxi. Jedná sa o oddelenie človeka od problému. Vychádza z koncepcie, ktorej sa pridržiavajú naratívni terapeuti, kde človek je človek a problém je problém. Terapeut pomáha klientovi bojovat's problémom, ktorý je akoby mimo klienta, ale ktorý do života klienta intenzívne zasahuje. Pracovník navrhuje ako zaobchádzat s problémom ktorý môže byt predstavovaný ako „obluda“, „diabol“ atd'. Navrhuje rôzne riešenia a spôsoby a motivuje klienta bojovat s tým, čo ho privádza do problémov. Externalizácia má velkú oblubu najmä u detí a je akousi hrou s problémom, snahou ho okabátit', prejst' cez rozum a pokial' sa nepodarí ho odstránit úplne, aspoň získat nad ním prevahu ${ }^{16}$.

Velkou výhodou terapie zameranej na riešenie je intenzita kontaktu s rodinou, podpora rastu klienta, ponuka služieb, ktoré klientovi vyhovujú, rozvíjanie ich

16 Pozri i. k. Berg, Posílnení rodiny, op. cit. 
kompetencií a pomoc v rôznych situáciách zachránit rodinu. Celý postup práce terapeuta sa dá vystihnút slovami - robit všetko, aby sme pre klienta boli užitoční.

\section{Bibliografia}

Berg i. k., Posílnení rodiny, Praha 2013.

de Shazer S., Zázračná otázka, Praha 2011.

Hangoni T., Zvyšovanie profesionálnych kompetencií sociálneho pracovníka, „Sociálna a Duchovná Revue", 1 (2010) 4., s. 61.

Pecháčková S., O systemické terapii, Praha 1992.

Koteková R. a kol., Psychológia rodiny, Košice 1998.

Fischer S., Sociální patologie. Analýza př́čin a možnosti ovlivňování závažných sociálně patologických jevů, Praha 2009.

Prevendárová J., Rodinná terapia a poradenstvo, Bratislava 2011, http://www.terapeutickecentrum.com/wp-content/uploads/2010/06/kniha.pdf. (10.05.2015). 
4. Uniwersytet Papieski 